\title{
Military Service in Early Sixteenth-Century Lithuania: A New Interpretation and Its Implications
}

The existence of compulsory military service has become a major theme in recent attempts to explain the development of Lithuanian society and politics in the early sixteenth century. Much of the discussion has centered on the relationship between military service and feudalism. This article concentrates not on that question but on the nature of military service and the understanding it can provide of the structure and dynamics of the economy of Lithuania in the sixteenth century.

The issue of feudalism has been thoroughly and persuasively dealt with in a recent article by Oswald Backus. ${ }^{1}$ As partial evidence for his conclusion that "it is very hard to argue that Lithuania was feudal in the period 1506-48" (p. 659), Backus contends that although military service was a general obligation, this obligation was not enforced by confiscation for nonperformance. In fact there is strong evidence to suggest that no such obligation existed. If such is the case, the traditional interpretation must be substantially revised.

A major source for determining whether military service was a condition for landholding is the Lithuanian Statute of 1529. There is no universal military service requirement set forth in the statute. On the basis of the statute and the troop register of 1528, it appears that the performance of military service was required only of those who held a rather restricted category of landed property-referred to in the statute as a zemskoe imenie. Those who did not hold such estates but only other types of property, such as patrimonial,

1. Oswald P. Backus, "The Problem of Feudalism in Lithuania, 1506-1548," Slavic Revieze, 21, no. 4 (December 1962) : 659. Backus's unstated assumption that the Extended General Land Privilege of 1529 was the original (Latin) manuscript of the Lithuanian Statute of 1529 may trouble the reader of his otherwise careful presentation. His notes $27,29,30,46,47$, and 59 , though supposedly referring to the statute, in fact refer to the privilege (published in M. K. Liubavsky, Ocherk istorii Litovsko-russkogo gosudarstva do Liublinskoi unii vkliuchitel'no, 2nd ed. [Moscow, 1915]), which was issued one month after the promulgation of the statute (published in K. I. Jablonskis, ed., Statut Velikogo kniazhestva Litovskogo 1529 goda [Minsk, 1960]). Although the actual manuscript of the privilege may be older than the earliest extant manuscript of the statute, the influence of the former on the latter is moot, and apparently demands a more detailed textological analysis than Backus could justifiably engage in within the parameters of his presentation. 
earned, or purchased estates, were apparently exempt from military service.

An examination of the use of the term zemskoe imenie is crucial to any understanding of the problem of military service. Early interpretations of the service provisions contained in the first article of section two (II: [1]) of the statute were based on the assumption that zemskoe imenie meant a landed estate in general. ${ }^{2}$ The clearest indication of the specific nature of the term is in article II: [1], where it is stated that "every prince and lord, and courtier [dvorianin] and widow ... who has a landed estate [zemskoe imenie] ... is obligated to serve in war . . . and to equip ... people . . from his estates patrimonial, earned, and purchased ..." (Jablonskis, Statut, p. 42). Apparently the recruits could be inhabitants of estates not directly related to military obligations; otherwise the compilers of the statute probably would not have deemed it necessary to mention the types of estates from which they could be drawn. The statute clearly distinguishes servitors who have a direct military obligation from the soldiers whom they are to "equip."

Although article II:[1] uses the term "landed estate," there does not seem to be a substantial difference between that term and simply "estate" (imenie). The adjective zemskii (land) most likely pertains exclusively to nobles. For instance, the rubric of section two is "Concerning Land Defense" ( $O$ oborone zemskoi), meaning, judging from the contents of the entire section, the defense of the state as performed by the nobles who held service estates and by their troops. It is not unlikely that this modifier is even more restrictive, applying exclusively to those nobles who held service estates. In the overwhelming majority of cases where the term imenie appears in the statute, it is used in the sense of an estate granted by the grand prince in exchange for future service. Thus it seems that the combination zemskoe imenie could in a sense be redundant.

There is a possibility that a landed estate was the same as one of the three types (patrimonial, earned, and purchased) enumerated in the article on service. However, the use of imenie and its assumed synonym zemskoe imenie tends to lessen this possibility. Article fourteen of section four contains the statement that all stepchildren "may receive an equal share in all [the stepfather's] estates and in the patrimony, the earned estate, and the purchase" (Jablonskis, Statut, p. 59). The three types appear to be very different. The provisions of article I:19 concern the possession of an estate (imenie) or patrimony (otchizna), suggesting that the two were not synonymous (p. 38). In article V:15 regarding the willing of property to the Catholic or Orthodox Church reference is made to estates or purchases (kupli), indicating that a purchase was something other than an estate (p. 67). If we assume that the

2. For example, M. K. Liubavsky, Oblastnoe delenie i mestnoe upravlenie Litovskorusskogo gosudarstva ko vremeni izdaniia pervogo Litovskogo statuta (Moscow, 1892), pp. 611-12. 
terminology employed by the compilers is consistent throughout the statuteand this is a valid assumption-then it would seem that an imenie was not a patrimonial (or matrimonial), earned, or purchased landholding, but indeed something quite distinct from all three.

Thus, from evidence presented in the statute, it appears that military service was required only of those who held a zemskoe imenie, and apparently was not as a general rule required of those who held patrimonial, earned, or purchased landholdings-landholdings which are to be distinguished from landed estates.

The troop register of May 1, 1528, is also a major source of evidence on the absence of a universal military service obligation. The register lists those who were required to provide troops and in what numbers. Each person was to send one horse with rider for every eight service units (sluzhby) of people that he held. ${ }^{3}$ The decree may be divided into two main sections. The first of these (cols. 7-21) is a random listing of various princes, lords, lords of the council, officials, assorted nobles, wives and widows of princes, lords, and so forth. The second major section (cols. 21-232) is basically a geographical listing that in some instances supplements the first. A few persons are listed in both parts-for example, Prince Ivan Vishnevetsky is cited under the general heading (col. 16) and under the geographical heading of Volynia, as the derzhavtsa or prefect of Eishish (col. 183). In the first listing he is to supply thirty-eight horses and riders; in the second, fourteen.

One item in the register adds credence to the claim that military service was not a general obligation of all landholders. In the listing for a Tatar named Vaskovich is found the only reference to a patrimony in the whole register. This Tatar alone was to perform service from his patrimony ( $z$ otchizny) $(R I B, 33: 110)$. Vaskovich is listed under the heading of those Tatars who had no "people," that is, no land grant; he is one of a group of over fifty "Tatar Cossacks." Any assumption that mention of a patrimony would be made if as a general rule possession of a patrimony entailed service lacks credibility. The manner in which this notation occurs and the complete absence of any other such notations suggest that service from a patrimony was an exception-indeed, a very rare exception.

In the troop register of 1565 there are numerous other instances of servitors from allodial estates $(R I B, 33: 313,314,425-26)$. The reason for these entries, as in the case above, is not immediately apparent. If we assume that service was required from all types of estates, these notations in the

3. Arkheograficheskaia komissiia, ed., Russkaia istoricheskaia biblioteka, vol. 33 (Petrograd, 1915), "Litovskaia Metrika, Otdel pervyi, Chast' tret'ia: Knigi publichnykh del, Perepisi voiska litovskogo," col. 7 (hereafter cited in the text as RIB). Vernadsky mistakenly claims that one horse and rider were to be provided for every ten service units. George Vernadsky, Russia at the Dazen of the Modern Age (New Haven, 1959), p. 190. 
register of 1565 may be nothing more than an indication of the kind of estate from which the troops were being drawn. However, the register of 1528 is not an enrollment list of troops but simply a draft call enumerating the number of horsemen required from each person who had an obligation to perform military service. At the time of the listing in 1528 those who were so obligated still were able to choose the estates from which they preferred to supply troops. The register of 1565 , however, is actually an enrollment of the troops sent by the various landholders. Perhaps for this reason there are more cases of troops from patrimonies and matrimonies in the register of 1565 than in that of 1528 . The two registers are not at all identical in intent. For the purposes of this discussion, then, only the listing of 1528 is appropriate.

The probability that Vaskovich's service from his patrimony was his option has already been ruled out by virtue of the nature of the document. There can be no explanation for this except that the possession of a patrimony did not as a rule in itself entail service, and that for some reason Vaskovich of all the nobles in the Grand Principality of Lithuania had to serve even though he held no service estate. Thus it seems that the exception of Vaskovich proves the rule assumed here-there was no universal service obligation.

Since it seems therefore that the ownership of allodial estates did not obligate the holder to perform service, the case for the absence of universal military service would be significantly strengthened if it could be determined that the possessors of extensive allodial estates were not cited at all, or only to a limited extent in the register of 1528 as being required to provide troops. Two major princely clans, the Riurikovichi and the Gediminovichi, owned major hereditary estates in the Grand Principality of Lithuania. ${ }^{4}$ These clans were the descendants of the $u d e l$ princes of the families of Riurik and Gedimin. The Riurikovichi princes owned their allods in the Russian areas of the state, and the Gediminovichi most frequently in the ethnic Lithuanian regions. The table on page 254, listing the major princely families and the number of horses each was to furnish, serves to indicate the extent of their obligations according to the register.

With regard to the Riurikovichi listed in the register, of those whose surnames appear there ten families are listed under the general heading of "princely companies" only, with no mention of them under the headings of those areas which Picheta and Liubavsky assert are their native provinces. If the possession of any sort of landholding obligated the holder to perform service, it could be argued that this lack of mention indicates that these families had lost their hereditary estates, but were listed because they had

4. V. I. Picheta, Istoriia sel'skogo khoziaistva v Belorussii, vol. 1: Do kontsa XVI v. (Minsk, 1927), pp. 56-57; Liubavsky, Ocherk, p. 194. 
in other areas nonallodial estates of one sort or another from which service was required. But if service was required only of those holding service estates, failure to mention them in their home regions would mean simply that although they still might own allodial estates in that region, they possessed no service estates.

Four families were to serve from their home regions, two of these (the Chetvertinskys and Sokolskys) solely from home regions. These four families may have been granted service estates adjoining their allods, and for this reason they had to perform service only from the former. Only the Lukomsky princes held estates in their native territory as well as elsewhere. This family -still assuming that only the possession of service estates entailed servicethus held both service estates adjoining its hereditary estates and other service estates as well.

In total number of horses demanded the Riurikovichi do not seem to be of major importance. The percentage of troops supplied by the major Russian hereditary princes was small-less than 2 percent of the total twenty thousand horses. Picheta claims this is an indication of just how impoverished these princes were (p. 60). This is of course a possible interpretation. If it were the case, however, the majority of the princes noted above would have been required to provide perhaps one or two horses, and such princes would be numerous, since the old patrimonies would have been divided many times among the descendants of the $u d e l$ princes. But many Riurikovich families are either not listed in their native regions or not in the register at all. Of the twenty-seven Riurikovichi, thirteen are not listed in their native territory, and ten are not listed at all. Most of the former are to be found under the general heading in the register, and others in territories not native for them. It would be a considerable coincidence if nearly half of the Riurikovichi in Lithuania had fled to Muscovy, died, or gone bankrupt.

Another possible explanation for the absence of these families is that the princes and lords had their troops under their own banners - a common practice, as Picheta correctly notes (p. 55). This option is part of the first article of section two of the statute. It might well be asserted that large companies standing apart under the banners of wealthy individuals were not noted in the register. But how might one justify the register notations of such lords as Gashtold (466 horses) or such princes as Ostrozhsky (426 horses)? There is no evidence that any individual was to supply more than Gashtold's 466 horses. Whether troops were to stand under a lord's banner or not, doubtless they were to be noted in the register. Consequently, within the limits of the geographical area covered by the register, it is difficult to accept as an explanation the claim that there were some very wealthy nobles who were liable for the performance of universally required military service, but who were not listed in the register. 
MAJOR RIURIKOVICHI FAMILIES

\begin{tabular}{|c|c|c|c|c|c|c|}
\hline \multirow[b]{2}{*}{$\begin{array}{c}\text { Families by } \\
\text { Native Region }\end{array}$} & \multirow{2}{*}{$\begin{array}{c}\text { Number } \\
\text { of Entries } \\
\text { in } \\
\text { Register }\end{array}$} & \multicolumn{5}{|c|}{ Number of Horses } \\
\hline & & $\begin{array}{l}\text { From } \\
\text { native } \\
\text { region }\end{array}$ & $\begin{array}{c}\text { In } \\
\text { general } \\
\text { listing }\end{array}$ & $\begin{array}{l}\text { From } \\
\text { Russian } \\
\text { regions }\end{array}$ & $\begin{array}{c}\text { From } \\
\text { Lithuanian } \\
\text { regions }\end{array}$ & Total \\
\hline \multicolumn{7}{|l|}{ POLOTSK LAND } \\
\hline $\begin{array}{l}\text { Lukomsky } \\
\text { Shchedutsky }\end{array}$ & $\begin{array}{r}11 \\
0\end{array}$ & 50 & 10 & & T-5 & $\begin{array}{r}65 \\
0\end{array}$ \\
\hline Meleshkovsky & 1 & & 22 & & & 22 \\
\hline Vedenitsky & 1 & & 3 & & & 3 \\
\hline \multicolumn{7}{|l|}{ VITEBSK LAND } \\
\hline Drutsky & 0 & & & & & 0 \\
\hline Tolochinsky & 1 & & 18 & & & 18 \\
\hline Sokolinsky & 6 & & 25 & P-23 & & 48 \\
\hline Ozeretsky & 2 & & 12 & & & 12 \\
\hline Odintsevich & 1 & & 33 & & & 33 \\
\hline Zubrevitsky & 0 & & & & & 0 \\
\hline Putiatich & 0 & & & & & 0 \\
\hline Gorsky-Shishevsky & 2 & & 21 & & & 21 \\
\hline Polubensky & 1 & & 43 & & & 43 \\
\hline Sensky & 2 & & 8 & & & 8 \\
\hline \multicolumn{7}{|l|}{ SMOLENSK LAND } \\
\hline Viazemsky & 1 & & & P-4 & & 4 \\
\hline Byvalitsky & 0 & & & & & 0 \\
\hline Kozlovsky & 0 & & & & & 0 \\
\hline Kroshinsky & 1 & & 17 & & & 17 \\
\hline Zhilinsky & 3 & & 3 & VI-9 & & 12 \\
\hline \multicolumn{7}{|l|}{ VOLYNIA } \\
\hline Chetvertinsky & 2 & 16 & & & & 16 \\
\hline Sokolsky & 3 & 9 & & & & 9 \\
\hline Ostrozhsky & 1 & & $426^{a}$ & & & $426^{a}$ \\
\hline Ruzhinsky & 0 & & & & & 0 \\
\hline Ostrozhetsky & 0 & & & & & 0 \\
\hline Nesvetsky & 0 & & & & & $\mathbf{0}$ \\
\hline Zbarazhsky & 0 & & & & & $\mathbf{0}$ \\
\hline Vishnevetsky & 5 & $26^{a}+20$ & 38 & & & 84 \\
\hline Totals & 44 & 121 & 679 & 36 & 5 & $841^{b}$ \\
\hline \multicolumn{7}{|c|}{ MAJOR GEDIMINOVICHI FAMILIES } \\
\hline \multicolumn{7}{|l|}{ Ethnic Lithuania } \\
\hline Gedroitsky & 0 & & & & & 0 \\
\hline Golshansky & 1 & & 122 & & & 122 \\
\hline Svirsky & 2 & & $5+11^{a}$ & & & 16 \\
\hline \multicolumn{7}{|l|}{ MinsK } \\
\hline Zheslavsky & 3 & & 45 & VO-29 & & 74 \\
\hline \multicolumn{7}{|l|}{ VoLYNIA } \\
\hline Buremsky & 2 & 4 & & & & 4 \\
\hline Chartoriisky & 2 & $33^{a}$ & 22 & & & 55 \\
\hline Koretsky & 2 & 20 & & & & 20 \\
\hline Sangushkovich & 3 & $42^{a}$ & 44 & & & 86 \\
\hline Totals & 15 & 99 & 249 & 29 & & $377 \mathrm{c}$ \\
\hline
\end{tabular}


If, however, service was the obligation only of those who held service estates, then it is quite possible that some nobles of substantial wealth were not listed in the register. Some patrimonial landholders are known to have held both their allodial estates and other-purchased or service-estates as well (Picheta, p. 57). This fact would account for those nobles who might have had to serve from one landholding (a service estate) and not from another (a patrimonial estate). In addition, the practice of augmenting one's allodial holdings with other types of landed property could also lead to no little confusion with regard to the determination of the relative wealth of nobles cited in the register. If service was demanded only of the holders of service estates, the following situation might have occurred: Noble A, who held the equivalent of one hundred service units of allodial estates and eight service units in service estates, would be required to furnish as many troops as relatively poor Noble B, who held only eight service units in service estates. The register is simply not a reliable index of wealth-nor, in all likelihood, was it intended to be.

If we accept the traditional interpretation of the service obligation as well as the assertion that "some" princes became impoverished or their landholdings became fragmented (Picheta, p. 57), an unusual situation would have prevailed: it would mean that nearly three-fourths of all the Riurikovichi acknowledged as being of substantial means had either lost their patrimonies or those patrimonies had diminished in size-twenty families, ten of which are not mentioned at all in the register and ten of which are included only under the general listing. Under these same two conditions only four families would have retained their patrimonies. It is more likely that some of the ten Riurikovich families not listed in the register-if indeed they still lived in the Grand Principality-were among those families Picheta refers to as retaining only their allods. The other ten families under the general listing quite possibly held patrimonial estates as well as service estates, the possession of the latter requiring the holders to perform service.

Although I have confined my remarks to the Riurikovichi, the case of the Gediminovichi does not appear to be unusual enough to suggest substantial variance with the basic conclusion presented here. The concept of a limited service obligation fully resolves apparent internal inconsistencies of the register -inconsistencies only if the traditional view of universal service is accepted.

In summary, there are three points which argue against the existence of compulsory military service: (1) in the statute zemskoe imenie and imeniethe possession of which carried the obligation to perform military servicedo not mean just any kind of landholding, but something other than an allodial, earned, or purchased estate; (2) service required because of the possession of a patrimony is in evidence in only one instance in the troop register of 1528 , suggesting that such a requirement was most unusual; (3) nearly 
one-third of the major allodial landholding families-Riurikovichi and Gediminovichi-were not obliged to provide horses and riders.

The conclusion that the performance of military service was not required of all landholders opens up some extremely significant avenues for new research. Since population estimates for Lithuania are based at least in part upon the troop register, ${ }^{5}$ and since we have concluded that the register does not include all allodial landowners, it appears that population estimates may have to be revised considerably upward. ${ }^{6}$ To what extent the figure of one-third allodial landowners not mentioned in the register is reflected in the underestimation of population cannot be determined at this point. Nor can we speculate on how many persons partially escaped service because some of their land was in allodial estates and some in service estates-being listed in the register, but not completely. What is needed is a meticulous examination of all available land grants and inventories to determine which of the landholdings in these documents are partially or wholly omitted from the register.

The existence on a large scale of such landholders promises even more intriguing possibilities. If there were large parcels of land owned by individual nobles who to a great extent had no responsibilities to the crown, what effect did such a situation have on the economic position of the crown? The Grand Principality, experiencing severe fiscal difficulties in its conflicts with Muscovy, quite possibly was faced with the problem of many resident landholders who simultaneously were free from the payment of taxes and were in successful competition with crown lands for markets. What were the dynamics of the problem? Were increasing amounts of land slipping out from under service and other obligations? It is possible that the Agrarian Reform of 1557 was carried out on crown lands as a palliative intended to make agricultural production more efficient and hence more nearly competitive with that of the independent landowners. This possibility raises the most fascinating issue of all: Could the Union of Lublin have been a result of fiscal difficulties of the crown, caused in large measure by its inability to compete for markets with private landowners?

Clearly there exists a critical need for more work on the Lithuanian economy and its impact on political developments. Such research doubtless will contribute significantly to a new understanding of the Grand Principality of Lithuania in the sixteenth century, and thereby increase our knowledge of this nodal point in the history of Eastern Europe.

5. For example, Vernadsky, Russia at the Dawn of the Modern Age, pp. 175-77.

6. For additional points indicating the difficulties involved in employing the register for population figures, see Józef Morzy, Kryzys demograficzny na Litwie i Bialorusi w II polowie XVII wieku (Poznań, 1965), pp. 4-5. 